Bulletin of Pharmaceutical Sciences
Assiut University
$\begin{gathered}\text { Website: http://lbpsa.journals.ekb.eg/ } \\ \text { e-mail: bullpharm@aun.edu.eg }\end{gathered}$

\title{
ASSESSING THE EFFECTS OF ORLISTAT AS AN ANTI-OBESITY DRUG IN HIGH FAT DIET INDUCED OBESITY IN MALE RATS
}

\author{
Enas Saleh Abdel-Baky* and Omnia Nasr Abdel-Rahman \\ Department of Biological and Geological Sciences, Faculty of Education, Ain Shams \\ University, Cairo, Egypt
}

\begin{abstract}
The present work was designed to evaluate the effectiveness of the orlistat drug on some hormones and biochemical parameters in male rats received a high fat diet (HFD). Twenty-four rats were divided into four groups: 1 st group administered normal diet, $2^{\text {nd }}$ group administered HFD, the 3rd group administered HFD plus $9.5 \mathrm{mg} / \mathrm{kg} \mathrm{b.w./day} \mathrm{orlistat,} \mathrm{and} \mathrm{the} \mathrm{4th} \mathrm{group}$ administered HFD diet plus $19 \mathrm{mg} / \mathrm{kg}$ b.w./day orlistat. The experimental period was for four weeks. At the end of the experiment, blood samples were obtained for biochemical and hormonal assays. The administration of HFD for four weeks increased significantly the weight gain, serum total cholesterol (TC), triglycerides (TAG), low density lipoprotein (LDL-c), glucose, insulin, triiodothyronine (T3), thyroxine (T4), leptin, with the significant decrease in high density lipoprotein $(H D L-c)$, ghrelin, thyrotropin (TSH) and testosterone hormones in the serum as compared with the control group. The treatment with orlistat neutralized the levels of the measured parameters as compared with HFD fed rats and the results were correlated with the dose of orlistat. In conclusion, an improvement was observed in the biochemical and hormonal results by the treatment with orlistat drug.
\end{abstract}

\section{INTRODUCTION}

Obesity is a chronic disease that results in the accumulation of excess fat in the body due to an energy imbalance. The obesity may be caused by multifactorial etiology, including lifestyle, environment, genetics, metabolism, and behavioral components ${ }^{1}$. The factors of lifestyle, such as regular physical activity, proper nutrition and changes in eating behaviors play an important role in combating obesity $^{2}$. Numerous diseases are caused by obesity, including hypertension, hypercholesteremia, sleep apnea, pulmonary hypertension, cardiovascular disease and type 2 diabetes $^{3}$. Martorell et al., reported that Egypt have the highest proportion of obesity $(20.1 \%)^{4}$.

Anti-obesity drugs are all pharmacological agents used to reduce or control weight. These medications alter one of the human body essential processes, either by altering appetite or absorption of calories ${ }^{5}$. Excessive fat intake is a common cause of the development of hyperlipidemia and obesity, a compound that selectively limits the absorption of ingested fat might be useful in both condition treatments ${ }^{6}$. Orlistat is a pharmacological agent facilitating the weight loss and the weight maintenance via inhibiting of pancreatic lipase, an enzyme that is necessary for the triglycerides digestion, it reduces the absorption of fat by $30 \%$ through three doses of $120 \mathrm{mg}$ daily ${ }^{7}$. There are no side effects of orlistat due to its lack of absorption ${ }^{8}$. So, we have investigated in the present study the the ameliorating of orlistat on some hormones and biochemical parameters in a high fat diet (HFD) induced animal model of obesity.

\section{MATERIALS AND METHODS}

Twenty-four male albino rats weighing $(150-160 \mathrm{~g})$ were included in the present research. The rats were obtained from National Organization for Drug Control and Research

Received in 19/11/2020 \& Accepted in 18/12/2020 
farm, Giza, Egypt. Rats were housed in well aerated cages under common and controlled laboratory conditions of relative humidity $(55 \pm 5 \%)$ and temperature $\left(25 \pm 5^{\circ} \mathrm{C}\right)$, with a natural and $12 \mathrm{~h} / 12 \mathrm{~h}$ light/dark cycle and were provided commercial rodent diet and water $a d$ libitum for one week for adaptation.

\section{Composition of normal diet (ND) and high fat diet (HFD)}

Two types of diets had been used in the present study, normal diet (ND) for control rats $^{9}$, and high fat diet (HFD) (30\%) for induction of the obesity in the rats 5 .

\section{Drug}

Orlistat is a potent, specific, irreversible inhibitor of pancreatic and gastric lipases. Also known as tetrahydrolipstatin, it is a chemically synthesized derivative of lipstatin, which is naturally produced by Streptomyces toxytricini ${ }^{10}$. Orlistat drug was obtained from the pharmacy in Cairo, Egypt. According to the equivalent therapeutic dosages of humanmouse conversion factor ${ }^{11}$, the dose of orlistat $(120 \mathrm{mg} / \mathrm{kg}$ b.wt.) was calculated and given for four weeks. The experimented rats were injected orally with orlistat that dissolved in the distilled water at low dose $(9.5 \mathrm{mg} / \mathrm{kg}$ b.wt.) and a high dose (19 mg/kg b.wt.).

After one week of the adaptation, the animals were divided randomly into four groups ( $n=6$ per group) as follows:

- Group 1 (G1): Served as a control group in which the rats received NFD for four weeks.

- Group 2 (G2): Served as HFD group in which the rats were fed a high fat diet for four weeks.

- Group 3 (G3): Rats received HFD and treated orally with a low dose of orlistat (9.5 $\mathrm{mg} / \mathrm{kg}$ ) daily for four weeks.

- Group 4 (G4): Rats received HFD and treated orally with a high dose of orlistat (19 $\mathrm{mg} / \mathrm{kg}$ ) daily for four weeks.

\section{Body weight gain}

The body weight gains for each rat were recorded before the initiation of the study (Day 0 ), and at the end of the experiment, then calculated for each group.

\section{Serum biochemical measurements}

At the end of the experimental period, the rats were fasted overnight. They were anaesthetized with diethyl ether and sacrificed by cervical dislocation. Then, the blood samples were collected, part of the blood was used for estimation serum glucose level enzymatically $^{12}$, using Spinreact diagnostics kits (Girona, Spain) and the second part of the blood was left to obtain the serum by centrifugation of the blood at $4000 \mathrm{rpm}$ for 10 min and stored at $-80^{\circ} \mathrm{C}$ immediately for further analyses.

Serum total cholesterol (TC), triglycerides (TAG) and high-density lipoprotein cholesterol (HDL-c) were measured by enzymatic colorimetric methods of Allain et al. ${ }^{13}$; Buccolo and David $^{14}$ and Kostener ${ }^{15}$, respectively. Whereas low density lipoprotein cholesterol (LDL-c) was calculated according to Friedewald et al. ${ }^{16}$, which is (in $\mathrm{mg} / \mathrm{dL}$ ):

$$
[\mathrm{LDL}-\mathrm{c}]=[\mathrm{TC}]-[\text { HDL-c }]-[\mathrm{TG} / 5]
$$

Leptin level was determined by the rat leptin ELISA kit (Crystal Chem Inc., USA) ${ }^{17}$. ELISA kits for measuring rat serum ghrelin were obtained from Abcam Biochemicals, $\mathrm{USA}^{18}$.

The insulin serum level was detected using the rat insulin ELISA kit (Crystal Chem Inc., Downers Grove, IL 60515, USA) ${ }^{19}$. Free tri-iodothronine (FT3) and free thyroxine (FT4) serum levels were measured using radioimmunoassay RIA kits (Institute of Isotopes, Budapest, Hungry). Serum thyroid stimulating hormone (TSH) was estimated by using RIA a specific rat TSH kit (supplied by Diagnostic Products Corporation DPC, Los Angeles, USA). Radioactivity was determined by the gamma-counter ${ }^{20}$. The serum testosterone level was assayed using kits of Hellabio biokits Company (USA) and following the manufacturer's instruction by ELISA radio immunoassay ${ }^{21}$.

Statistical analysis was carried out by a computer program using SPSS program (Version 16) ${ }^{22}$. The significant differences among groups were determined by one-way analysis of variance (ANOVA). The analysis followed by post hoc test using Duncan test to compare significance between each two groups at $\mathrm{p}$-value $<0.05$. Percentage difference $(\% \mathrm{D})$ calculated by the following equation:

$$
\frac{\text { Treated value }- \text { Control Value }}{\text { Control Value }} \times 100
$$




\section{RESULTS AND DISCUSSION}

Table 1 shows that the initial body weight revealed a non significant change between all groups. Whereas, the final body weight was significantly increased in a high fat diet (HFD) rats. Also, the data revealed that TC, TAG, LDL-c, LDL-c/HDL-c and TC/HDL-c were significantly increased in HFD group. This was accompanied with a significant decrease in serum HDL-c as compared to control animals (Table 2). Table 3 shows that the daily administration of HFD resulted in a significant increase in glucose, insulin and leptin serum levels, while ghrlein level was significantly decreased compared to normal-diet fed male rats. According to table 4, HFD induced a marked decrease in the levels of $\mathrm{T}_{3}, \mathrm{~T}_{4}$ and testosterone hormones, along with increasing level of TSH hormone in comparison with the control group.

All the mentioned parameters that measured in the present study were ameliorated to some extent in orlistat treated groups and the treatment revealed a dose-dependent manner.

Table 1: Initial body weight and final body weight in control and treated groups.

\begin{tabular}{||l|c|c|c|c|c|c|c|c||}
\hline & Group 1 & Group 2 & $\%$ & Group 3 & $\%$ & Group 4 & $\%$ & $\begin{array}{c}\text { P- } \\
\text { value }\end{array}$ \\
\hline $\begin{array}{l}\text { Initial body } \\
\text { weight (g) }\end{array}$ & $155^{\mathrm{a}} \pm 1.2$ & $154^{\mathrm{a}} \pm 1.4$ & -0.6 & $155^{\mathrm{a}} \pm 1.6$ & 0 & $155^{\mathrm{a}} \pm 1.7$ & 0 & - \\
\hline $\begin{array}{l}\text { Final body } \\
\text { weight (g) }\end{array}$ & $177.4^{\mathrm{a}} \pm 1.7$ & $252.6^{\mathrm{b}} \pm 2.2$ & 42.4 & $213.8^{\mathrm{c}} \pm 1.3$ & 20.5 & $203.4^{\mathrm{d}} \pm 1.5$ & 14.7 & $*$ \\
\hline
\end{tabular}

Means values + S.E. within the same column having different letters are significantly different means p-value $<0.05$. Same letters indicate non significant changes.

Table 2: TC, TAG, HDL-c and LDL-c levels in control and treated groups.

\begin{tabular}{||l|c|c|c|c|c|c|c|c||}
\hline & Group 1 & Group 2 & $\%$ & Group 3 & $\%$ & Group 4 & $\%$ & $\begin{array}{c}\text { P- } \\
\text { value }\end{array}$ \\
\hline \begin{tabular}{l} 
TC $(\mathrm{mg} / \mathrm{dl})$ \\
\hline $\begin{array}{l}\text { TAG } \\
(\mathrm{mg} / \mathrm{dl})\end{array}$
\end{tabular} & $82^{\mathrm{a}} \pm 1.5$ & $144.33^{\mathrm{b}} \pm 1.9$ & 76 & $103.8^{\mathrm{c}} \pm 1.9$ & 26.6 & $88.83^{\mathrm{d}} \pm 1.1$ & 8.3 & $*$ \\
\hline $\begin{array}{l}\text { HDL-c } \\
(\mathrm{mg} / \mathrm{dl})\end{array}$ & $48.2^{\mathrm{a}} \pm 3.4$ & $37.83^{\mathrm{b}} \pm 2.2$ & 55.1 & $82.5^{\mathrm{c}} \pm 1.8$ & 30.5 & $74.2^{\mathrm{d}} \pm 1.7$ & 17.4 & $*$ \\
\hline $\begin{array}{l}\text { LDL-c } \\
(\mathrm{mg} / \mathrm{dl})\end{array}$ & $21.2^{\mathrm{a}} \pm 2.4$ & $85.1^{\mathrm{b}} \pm 4.9$ & 302.8 & $43.66^{\mathrm{c}} \pm 1.7$ & 106 & $25.7^{\mathrm{d}} \pm 1.1$ & 21.23 & $*$ \\
\hline
\end{tabular}

Means values + S.E. within the same column having different letters are significantly different means p-value $<0.05$. Same letters indicate non significant changes. 
Table 3: Glucose, insulin, leptin and ghrlin levels in control and treated groups.

\begin{tabular}{||l|c|c|c|c|c|c|c|c||}
\hline & Group 1 & Group 2 & $\%$ & Group 3 & $\%$ & Group 4 & $\%$ & P-value \\
\hline $\begin{array}{l}\text { Glucose } \\
(\mathrm{mg} / \mathrm{dl})\end{array}$ & $88^{\mathrm{a}} \pm 2.02$ & $154.5^{\mathrm{b}} \pm 2.9$ & 75.6 & $124^{\mathrm{c}} \pm 1.9$ & 41 & $105.2^{\mathrm{d}} \pm 1.8$ & 19.5 & $*$ \\
\hline $\begin{array}{l}\text { Insulin } \\
(\mathrm{pg} / \mathrm{ml})\end{array}$ & $1.6^{\mathrm{a}} \pm 0.1$ & $3.7^{\mathrm{b}} \pm 0.1$ & 131.1 & $2.6^{\mathrm{c}} \pm 0.13$ & 62.5 & $2.2^{\mathrm{d}} \pm 0.1$ & 37.5 & $*$ \\
\hline $\begin{array}{l}\text { Leptin } \\
(\mathrm{ng} / \mathrm{ml})\end{array}$ & $3.9^{\mathrm{a}} \pm 0.1$ & $7.5^{\mathrm{b}} \pm 0.12$ & 92.3 & $6.1^{\mathrm{c}} \pm 0.1$ & 56.4 & $5.03^{\mathrm{d}} \pm 0.1$ & 29 & $*$ \\
\hline $\begin{array}{l}\text { Ghrlein } \\
(\mathrm{ng} / \mathrm{ml})\end{array}$ & $0.9^{\mathrm{a}} \pm 0.1$ & $0.5^{\mathrm{b}} \pm 0.043$ & -44.4 & $0.7^{\mathrm{c}} \pm 0.04$ & -22.2 & $0.8^{\mathrm{ac}} \pm 0.1$ & -11.1 & $*$ \\
\hline
\end{tabular}

Means values + S.E. within the same column having different letters are significantly different means p-value $<0.05$. Same letters indicate non significant changes.

Table 4: $\mathrm{T}_{3}, \mathrm{~T}_{4}, \mathrm{TSH}$ and testosterone hormones levels in control and treated groups.

\begin{tabular}{||c|c|c|c|c|c|c|c|c|}
\hline & Group 1 & Group 2 & $\%$ & Group 3 & $\%$ & Group 4 & $\%$ & P-value \\
\hline $\begin{array}{l}\mathrm{T}_{3} \\
(\mathrm{ng} / \mathrm{L})\end{array}$ & $1.5^{\mathrm{a}} \pm 0.04$ & $0.9^{\mathrm{b}} \pm 0.03$ & -40 & $1.23^{\mathrm{c}} \pm 0.03$ & -18 & $1.4^{\mathrm{a}} \pm 0.04$ & -6.7 & $*$ \\
\hline $\begin{array}{l}\mathrm{T}_{4} \\
(\mathrm{ng} / \mathrm{dl})\end{array}$ & $2.7^{\mathrm{a}} \pm 0.1$ & $1.8^{\mathrm{b}} \pm 0.1$ & -33.3 & $2.13^{\mathrm{c}} \pm 0.1$ & -21.11 & $2.44^{\mathrm{d}} \pm 0.1$ & -9.6 & $*$ \\
\hline $\begin{array}{l}\mathrm{TSH} \\
(\mathrm{uIU} / \mathrm{ml})\end{array}$ & $0.5^{\mathrm{a}} \pm 0.02$ & $0.7^{\mathrm{b}} \pm 0.022$ & 40 & $0.53^{\mathrm{c}} \pm 0.014$ & 6 & $0.5^{\mathrm{ac}} \pm 0.02$ & 0 & $*$ \\
\hline $\begin{array}{l}\text { Testos- } \\
\text { terone } \\
(\mathrm{ng} / \mathrm{ml})\end{array}$ & $1.5^{\mathrm{a}} \pm 0.06$ & $0.9^{\mathrm{b}} \pm 0.06$ & -40 & $1.2^{\mathrm{c}} \pm 0.1$ & -20 & $1.4^{\mathrm{ac}} \pm 0.1$ & -6.7 & $*$ \\
\hline
\end{tabular}

Means values + S.E. within the same column having different letters are significantly different means p-value $<0.05$. Same letters indicate non significant changes.

\section{All Tables}

The incidence of obesity is progressively rising worldwide and reaching epidemic proportions in some countries ${ }^{23}$. The current study aimed to evaluate the impact of obesity development on the indices of some biochemical parameters and certain hormones of male albino rats and the probable protective effects of the orlistat as anti-obesity drug on these parameters. Orlistat is a weight-loss drug with minimal systemic absorption ${ }^{24}$, and therefore any effect of this drug is a result of weight loss and not a direct effect on the body. In this work, feeding rats with a high fat diet (HFD) has been used to develop experimental obesity in male rats. The present data revealed a hyperlipidemia, hyperglycemia and hyperinsulinemia and were characterized by the elevated weight gain, total cholesterol (TC), triglycerides (TAG), low density lipoprotein LDL-c, glucose, insulin, $\mathrm{T}_{3}, \mathrm{~T}_{4}$ and leptin levels, with a significant decrease in HDL-c, ghrelin, TSH and testosterone hormones in the serum as compared with control group. These results are in harmony with previous researches ${ }^{25 \& 26}$, which demonsterated that diets containing a high proportion of saturated fatty acids resulted in elevated the plasma concentrations of TC and LDL Cholesterol. Also, the present elevated serum insulin level in the obese rats as compared with the corresponding controls were in accordance with that Abdel-Nabi et al. ${ }^{27}$. A selective hepatic insulin resistance, a hallmark of obesity, is manifested by a failure to inhibit gluconeogenesis ${ }^{28}$. So, the hyperglycemia and 
hyperlipidemia that were recorded in the present study may be attributed to the hepatic insulin resistance induced by $\mathrm{HFD}^{29}$. Since, free fatty acids (FFA) released from fat deposits, especially visceral fat, can block the insulin signal pathways directly and thus interrupt insulin action ${ }^{30}$. Also, consistent with the present results, a HFD has been shown to cause weight gain in the rats, mild hyperglycemia, hyperinsulinemia and impairment in blood glucose regulation, hypertriglyceridemia, hypercholesterolemia ${ }^{31}$.

Treatment of obese rats with the orlistat improved the previous results towards the normal control levels. The improvement resulted from therapy with orlistat may be attributed to its effect on the body's ability to absorb dietary fats ${ }^{32}$, and the reduction of the enzymatic activity that mediated through the covalent binding of orlistat to the serine residue of the lipase active site $^{33}$. Orlistat was used as a positive control because of its effectiveness in managing weight by reducing leptin levels and fat mass ${ }^{34}$. Orlistat changes the amount of fat delivered to the liver as well as the type of fat, thereby modulating insulin action to reduce the absorption of dietary fat ${ }^{35}$.

Our results revealed that the circulating level of the anorexigenic hormone leptin is increased, whereas surprisingly, the level of the orexigenic hormone ghrelin is decreased in response to a HFD compared with the control rats. These findings are in agreement with various studies Venner et al. ${ }^{36}$ and Antunes et $a l{ }^{37}$. These findings indicated that obesity is a state of leptin resistance. Leptin resistance has been shown to exist in obese human patients, who are hyperphagic but have very high serum leptin levels ${ }^{38}$.

Concerning with the testosterone hormone level in this study, the results were in concordance with observed a reduction in testosterone levels in Sprague-Dawley rats fed a HFD from weaning at 90 days $^{39}$. The reduction in testosterone level in the obesity rats may be attributed to transform of testosterone into estrogen which decreases testicle stimulation ${ }^{40}$, or may be due to the induction of induces lipid metabolic disorder by a HFD as reported by the results of this work and leads to a loss of male reproductive function, such as low serum testosterone level, sexual hormones metabolic changes, several adverse reproductive outcomes ${ }^{41}$.

A significant decrease in the level of $\mathrm{FT}_{3}$ and $\mathrm{FT}_{4}$, while a significant increase occurred in the level of TSH hormone were reported in the present obese rats comparing with the control ones. These results seemed to be in complete accordance with earlier studies ${ }^{42}$. These results may be attributed to the disturbance in hypothalamus-pituitary axis, the conversion of $\mathrm{FT}_{3}$ to $\mathrm{FT}_{4}$ or/and conversion of reverse $\mathrm{FT}_{3}$ to $\mathrm{FT}_{4}$ as a result of feeding rats on a HFD causing hypothyroidism. So, the thyroid disorders might participate in the pathogenesis of obesity.

It could be suggested that the ability of orlistat to ameliorate the testosterone level and thyroid functions may be attributed to modulating the action of insulin and lipid metabolism. This suggestion need more studies to support it.

On the basis of the present results, we concluded that the disturbance that occurred in the levels of some biochemical parameters and certain hormones in obese rats induced by a high fat diet could be ameliorated by the orlistat administration and the treatment was correlated with the dose used.

\section{Acknowledgements}

We thank Dr. Yasser Ashry Mohamed Aly Khadrawy for statistical advice. Also, the authors are grateful to the Department of Biological and Geological Sciences, Faculty of Education, Ain Shams University, for the availability of the place during caring of the animals.

\section{REFERENCES}

1- S. O. Lee, A. L. P.A. Simons, P. A. Murphy and S. Hendrich, "Soyasaponins lowered plasma cholesterol and increased fecal bile acids in female golden Syrian hamsters", Exp. Biol. Med., 230, 472-478 (2005).

2- R. M. P. Rao, Y. Jyothi and S.I. Rabban, "Anti-obesity activity of Taraxacum officinale in high fat diet induced obese rats", J. Chem. Pharm. Res., 7 (4), 244248 (2015). 
3- K. M. Gadde, C. K. Martin, H-R. Berthoud and S. B. Heymsfield, "Obesity: Pathophysiology and management", $\boldsymbol{J}$. Am. Coll. Cardiol., 71 (1), 69-84 (2018).

4- R. Martorell, L. K. Khan, M. L. Hughes and L. M. Grummer-Straw, "Obesity in women from developing countries", Eur. J. Clin. Nutr., 54 (3), 247-52 (2000).

5- H. M. Amin, N. S. Tawfek, B. K. Abo-El Hussein and M. S. Abd El-Ghany, "Antiobesity potential of orlistat and amphetamine in rats fed on high fat diet", Middle East J. Appl. Sci., 5 (2), 453-461 (2015).

6- C. A. Williams, F. Goldstone and J. Greenham, "Flavonoids, cinnamic acids and coumarins from the different tissues and medicinal preparations of Taraxacum officinale", Phytochemistry, 42 (1), 121127 (1996).

7- B. White, Y. Hsia, S. Kinra, S. Saxena, D. Christie, M. V. Russell and C. K. W. Ian, "Survey of antiobesity drug prescribing for obese children and young people in UK primary care", BMJ Paediatrics Open, 1 (1), e000104 (2017).

8- D. S. WEIGLE, "Pharmacological therapy of obesity: Past, present, and future", $\boldsymbol{J}$. Clin. Endocr. Metab., 88 (6), 2462-2469 (2003).

9- T. D. Pugh, R. G. Klopp and R. Weindruch, "Controlling caloric consumption: Protocols for rodents and rhesus monkeys", Neurobiol. Aging., 20 (2), 157-165 (1999).

10- B. Borgstrom, "Mode of action of tetrahydrolipstatin, a derivative of the naturally occurring lipase inhibitor lipstatin", Biochim. Biophys. Acta., 962 (3), 308-316 (1988).

11- G. E. Paget and J. M. Barnes, "Toxicity Tests", In: "Evaluation of Drug Activities: Pharmacometrics", D. R. Laurence \& A. L. Bacharach, Eds., Academic Press, London and New York, Vol. I (part 1), 1969, pp. 135-166.

12- P. Trinder, "Determination of blood glucose using 4-amino phenazone as oxygen acceptor", J. Clin. Pathol., 22 (2), 246 (1969).

13- C. C. Allain, N. Richmond and P. Rosechloy, "Cholesterol enzymatic colorimetric test", Clin. Chem. Clin., 19 (20), 1350-1470 (1974).

14- G. Buccolo and H. David, "Ouantitative determinarion of serum triglycerides by use enzymes", Clin. Chem., 19 (5), 478482 (1973).

15- C. M. Kostener, "Enzymatic determination of cholesterol high density lipoprotein fraction prepared by polyanion precipitation", J. Clin. Chem., 22 (5), 695 (1976).

16- W. T. Friedewald, R. I. Levy and D. S. Fredrickson, "Estimation of the concentration of low-density lipoprotein cholesterol in plasma, without use of the preparative ultra centrifuge", Clin. Chem., 18 (6), 499-502 (1972).

17- T. M. Mizuno, K. A. Kelley, G. M. Pasinetti, J. I. Roberts and C. V. Mobbs, "Transgenic neuronal expression of proopiomelanocortin attenuates hyperphagic response to fasting and reverses metabolic impairments in leptindeficient obese mice", Diabetes, 52 (11), 2675-2683 (2003).

18- E. Samy and F. S. Hussein, "Effect of exercise and orlistat therapy in rat model of obesity induced with high fat diet", Med. J. Cairo Univ., 81 (2), 59-67 (2013).

19- M. Ristow, H. Mulder, D. Pomplun, T. J. Schulz, K. Muller-Schmehl, A. Krause, M. Fex, H. Puccio, J. Müller, F. Isken, J. Spranger, D. Müller-Wieland, M. A. Magnuson, M. Möhlig, M. Koenig and A. F. Pfeiffer, "Frataxin deficiency in pancreatic islets causes diabetes due to loss of beta cell mass", J. Clin. Invest., 112, 527-534 (2003).

20- I. J. Chopra, D. H. Solomon and R.S. Gnho, "A radioimmunoassay of thyroxin", J. Clin. Endocrinol., 33 (5), 865-867 (1971).

21- J. D. Wilson and D. W. Foster, "Willams Textbook of Endocrinology", Philadelphia Saunders, 1992, pp. 923-926.

22- A. S. Glantz, "Primer of Biostatistics", MC Graw-Hill, Inc. U.S.A., 1992, pp. 218.

23- D. Yach, D. Stuckler and K. D. Brownell, "Epidemiologic and economic consequences of the global epidemics of obesity and diabetes", Nat. Med., 12, 6266 (2006). 
24- R. S. Padwal and S. R. Majumdar, "Drug treatments for obesity: Orlistat sibutramine, and rimonabant", Lancet, 369 (9555), 71-77 (2007).

25- H. J. Pownall, J. Shepherd, W. W. Mantulin, L. A. Sklar and A. M. Gotto, "Effect of saturated and polyunsaturated fat diets on the composition and structure of human low density lipoproteins", Atherosclerosis, 36, 299-314 (1980).

26- S. M. Grundy and G. L. Vega, "Plasma cholesterol responsiveness to saturated fatty acids", Am. J. Clin. Nutr., 47 (5), 822-824 (1986).

27- I. M. Abdel-Nabi, A. G. Kalifa, H. H. Ahmed, E. F. Eskander and A. H. Sayed, "The impact of obesity on some hormones and cognitive function among school girls", New York Sci. J., 3 (4), 66-71 (2010).

28- M. S. Brown and J. L. Goldstein, "Selective versus total insulin resistance: A pathogenic paradox", Cell Metab., 7 (2), 95-96 (2008).

29- M. Laplante and D. M. Sabatini, "mTORC1 activates SREBP-1c and uncouples lipogenesis from gluconeogenesis", Proc. Natl. Acad. Sci. U. S. A., 107 (8), 3281-3282 (2010).

30- J. R. Zierath, J. N. Livingston, A. Thörne, J. Bolinder, S. Reynisdottir, F. Lönnqvist and P. Arner, "Regional difference in insulin inhibition of non-esterified fatty acid release from human adipocytes: Relation to insulin receptor phosphorylation and intracellular signaling through the insulin receptor substrate-1 pathway", Diabetologia, 41, 1343-1354 (1998).

31- T. Stroubini, A. Perelas, C. Liapi, D. Perrea, I. Donta and C. Tzavara, "Serum adiponectin and resistin in rats under three isocaloric diets: The Effect of sibutramine", Cytokine, 46, 171-175 (2009).

32- F. X. Pi-Sunyer, "A review of long-term studies evaluating the efficacy of weight loss in ameliorating disorders associated with obesity", Clin. Ther., 18, 1006-1035 (1996).

33- I. Asler, M. Zehl and F. Kovaci, "Mass spectrometric evidence of covalentlybound tetrahydrolipstatin at the catalytic serine of Streptomyces rimosus lipase", Biochim Biophys Acta., 1770, 163-170 (2007).

34- G. Karimi, M. R. Sabran, R. Jamaluddin, K. Parvaneh, N. Mohtarrudin, Z. Ahmad, H. Khazaai and A. Khodavandi, "The antiobesity effects of lactobacillus casei strain Shirota versus orlistat on high fat dietinduced obese rats", Food Nutr. Res., 59, 29273 (2015).

35- N. Assy, O. Hussein and Z. Abassi, "Weight loss induced by orlistat reverses fatty infiltration and improves hepatic fibrosis in obese patients with nonalcoholic steatohepatitis", Gut, 56 (3), 443-444 (2007).

36- A. A. Venner, M. E. Lyon and P. K. Doyle-Baker, "Leptin: A potential biomarker for childhood obesity?", Clin. Biochem., 39, 1047-1056 (2006).

37- H. Antunes, C. Santos and S. Carvalho, "Serum leptin levels in overweight children and adolescents", Br. J. Nutr., 28, 1-5 (2008).

38- Y. Zhao, L. Chen, S. Mao, H. Min and J. Cao, "Leptin resistance was involved in susceptibility to overweight in the striped hamster re-fed with high fat diet", Sci. Rep., 8, 920 (2018).

39- R. M. Vigueras-Villaseñor, J. C. RojasCastañeda, M. Chávez-Saldaña, O. Gutiérrez-Pérez, M. E. García-Cruz, O. Cuevas-Alpuche, M. M. Reyes-Romero and E. Zambrano, "Alterations in the spermatic function generated by obesity in rats", Acta. Histochem., 113 (2), 214-220 (2011).

40- M. El-Sweedy, N. Abdel-Hamid and M. El-Moselhy, "The role of a mixture of green tea, turmeric and chitosan in the treatment of obesity-related testicular disorders", J. Appl. Biomed., 5, 131-138 (2007).

41- S. Amjad, M. Baig, N. Zahid, S. Tariq and R. Rehman, "Association between leptin, obesity, hormonal interplay and male infertility", Andrologia, 51, e13147 (2019).

42- H. N. Yousef and A. A. Saleh, "Lipid Profile and some hormonal disorders in serum of high-fat diet fed rats", Egypt. J. Hosp. Med., 53, 615-623 (2013). 


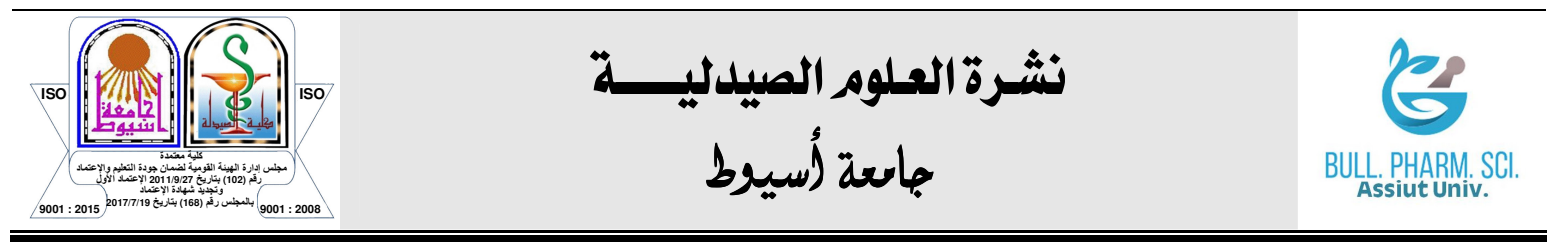

\section{تقييم تأثير الأورليستات كعقار مضاد للسمنة على السمنة المستحثة بنظام غذائى عالى الاهون في ذكور الجرذان}

$$
\text { إيناس صالح عبد الباقى - أمنية نصر عبد الرحمن }
$$

قسم العلوم البيولوجية والجيولوجية ، كلية التربية ، جامعة عين شمس ، القاهرة ، مصر

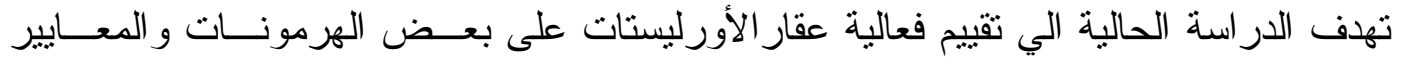

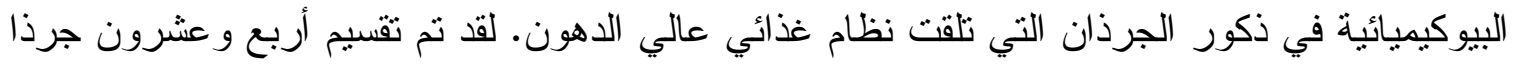

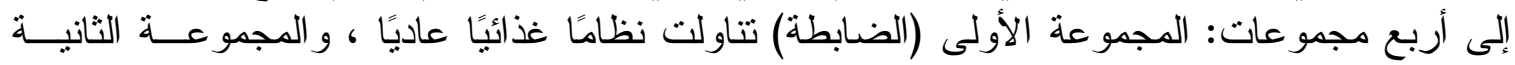

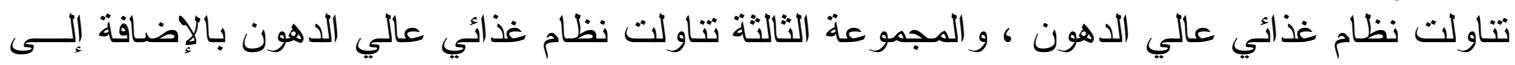

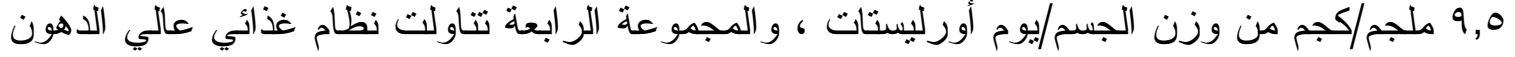

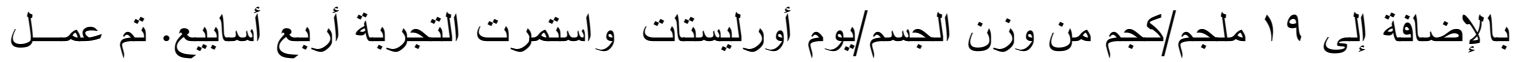

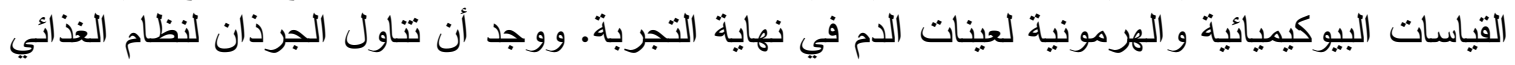

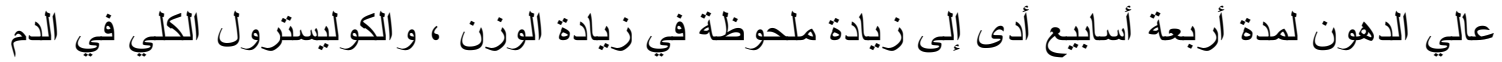

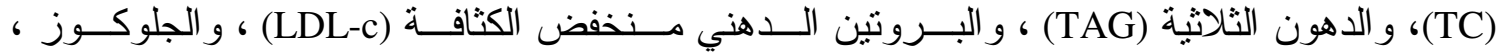

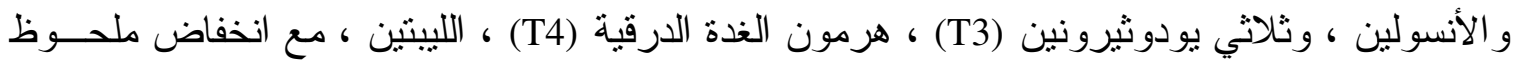

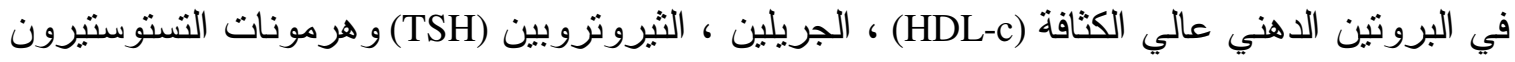

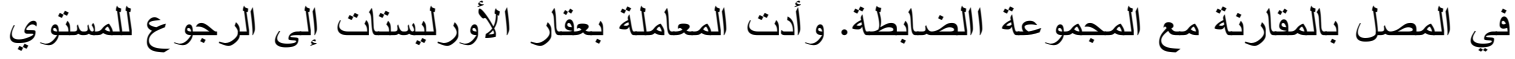

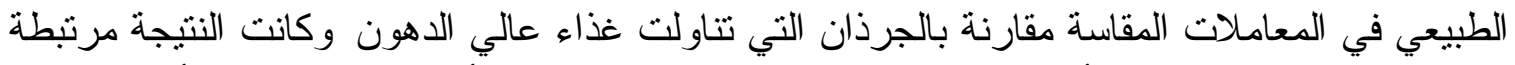

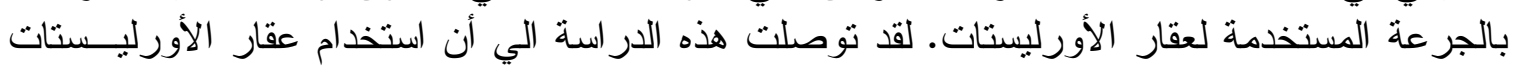

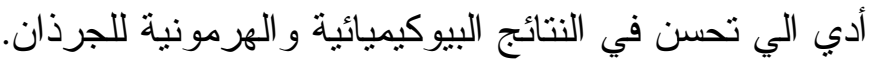

